Exploring the Politics of the Minimum Wage

by

Oren M. Levin-Waldman*

Working Paper No. 176

November 1996

*Resident Scholar, The Jerome Levy Economics Institute of Bard College 
For the most part, since its inception in 1938, the minimum wage has hovered around 55 percent of average annual hourly wages for production and nonsupervisory workers. Between 1981 and 1989, the minimum wage fell below 40 percent and it again fell below 40 percent between 1990-1996. For some, the failure of the minimum wage to keep pace with inflation is a matter of deliberate government policy aimed at creating a low-wage economy (Piore, 1995; Prasch, 1996). For others -- mainly the mainstream of the economics profession -- the fact that the minimum wage was not increased is really a testament to the soundness of economic analysis that holds minimum wage increases to be detrimental to the economy as a whole. Both perspectives, however, may be problematic. The first assumes that government may be a monolithic structure and as such can easily reach a unitary decision. Government is not. Rather it is -- at least in the U.S. -- a collection of institutions, actors and processes that occasionally achieve some coherence on the basis of consensus. More often than not, however, different actors in different institutions follow their own respective agendas. And the second is problematic because it assumes that economic models alone drive the policy process. They simply do not. Rather policy is a function of a mix of variables and are highly contingent on the various interests and actors involved (Kingdon, 1984; Stone, 1988). It is more the case that interests will rely on economic models when they serve to buttress their arguments.

In this paper I intend to argue that the minimum wage, as much as it is a serious economic issue, is above all else a political one. The minimum wage is a political issue on several levels. On one level, there are the politics surrounding the choice of models. On another level, there are the 
political interests of those who engage in the debate. Unlike entitlement programs, the minimum wage is not indexed to inflation. Rather it requires an act of Congress. Congress, however, is comprised of members whose primary obligation is to serve the constituents of their respective districts (Mayhew, 1974; Kau, Keen \& Rubin, 1982). If it isn't in the interest of their district -and regardless of party position -- members will vote against increasing the minimum wage. Another way to state this is to say that even if a member's party favors an increase in the minimum wage, that member may still be inclined to vote against it if his/her constituency has an interest in not raising it.

The purpose of this paper is to look at a variety of political issues surrounding the minimum wage. I specifically examine how the politics in the choice of methodological models can lead to different ideological positions which ultimately will get played out in the political arena. To this end, I organize the paper as follows: I first examine the debate between two models -- "demand constrained" vs. "supply constrained" -- and the ideological implications that flow from each. From there I explore why it is that one particular model has become the political focus of the debate at the expense of others. What I hope to show is that because conclusive data on the minimum wage has been so lacking the issue has been ripe for political manipulation. Nowhere do the politics of minimum wage show themselves to be of greater importance than in those regions of the country with "right-to-work" laws. The final section of the paper, then, looks at the voting patterns of members of Congress. It is no secret that Democrats have traditionally favorcd minimum wage increases while Republicans have opposed them. The focus of this paper is on the exceptions. What I intend to show is that Democratic members of Congress, when they come from "right-to-work" states, tend to vote against minimum wage increases even though 
Democrats traditionally favor it. Similarly, Republican members, when they come from those states with higher union density, tend to vote for minimum wage increases even though Republicans traditionally oppose it. This isn't to say that traditional economics models won't have a bearing. Indeed they may, particularly in the absence of strong constituent interest one way or the other. On the whole, though, members listen to their constituents. What I would like to suggest, then, is that given the fact that empirical data on the effects of the minimum wage has been ambiguous at best -- a fact that in and of itself makes the choice of models political with regards to implications -- it is more likely that minimum wage increases will occur when there is strong political support for them. Or more to the point, minimum wage increases are more likely to occur when strong political arguments can be made on their behalf.

\section{Competing Models}

Politics, as Harold Laswell stated so long ago, is about who gets what, when and where (Laswell, 1936). Stated in terms of the minimum wage, it is about who benefits from a minimum wage increase and who bears the costs. The economics literature is replete with studies demonstrating the ill effects of the minimum wage on a particular segment of the labor market. And while these studies are predicated on a particular model, the fact that this particular focus has been taken ultimately says more about politics than the merits of the model per se. Data on the effects of the minimum wage is simply inconclusive (Lcviton \& Belous, 1979; Brown, 1988). The traditional neo-classical economics model is a standard textbook analysis which holds the costs to society of raising wages to be far greater than any benefits. As the cost of labor is increased the demand for labor decreases. Only if the demand for goods and services on the part of consumers 
is increased can it be expected that there will be an increased demand for labor that will effectively bid up wages. A policy which artificially raises wages to help some at the expense of others is simply inefficient. Even if there is some outward appearance of benefit to be derived from an increase in the wage floor, there will invariably be a cost to be borne whether in the form of job loss, lost opportunity for jobs, lost benefits or increased output per man hours -- the demand for higher productivity.

This, of course, is a theoretical construct which hasn't conclusively been proven in the real world. On the contrary, in the real world, the minimum wage is likely to affect different people differently. Therefore, the debate over it is ultimately about politics and ideology. On one level, the nature of the debate has been shaped by the dearth of empirical literature that could demonstrate categorically that increases in the minimum wage would have the predicted textbook effect. On another level, it has been shaped by a fundamental difference between two models, both of which carry their own serious respective repercussions. One model which is "Demand constrained" assumes the minimum wage to have its primary impact on the behavior of employers and their subsequent demand for labor. The minimum wage leads to lower levels of employment because it constrains the demand for labor. The other model which is "Supply constrained" assumes that the level of the wage affects the supply of labor into the market. The higher the minimum wage, the more likely it is to attract individuals into the labor market. Although both models may have validity in theory, which in turn would imply the need for public policy to strike a balance between the two, the problem thus far has been data. Considerable data exists to suggest that the demand constrained model holds true, at least among teenagers. But there isn't any data to suggest that the supply constrained model holds, that it could be the basis upon which 
poverty is alleviated. And yet, those who argue the supply constrained model often call for minimum wage increases as a way of assisting the poor. Inevitably, then, the political debate becomes one of youth disemployment effect vs. poverty. What is often overlooked in this debate is that there may well be other political reasons for either supporting or opposing the minimum wage. And perhaps the most unfortunate consequence has been that we have lost sight of the larger macroeconomic arguments for the minimum wage.

The specific focus of the demand constrained model has been on the youth labor market. For the longest period, the prevailing wisdom has been that the minimum wage exacts its greatest toll on the youth labor market, that a binding wage floor will reduce employment for younger and less-skilled workers. Meyer and Wise in a study for the 1973-78 period estimated that if there were no minimum wage, employment among out-of school male youth 16-19 years of age would have been about 4 percent higher and employment of those 20-24 would have been 2 percent higher. And the employment increases would have been even greater among black youth: 6 percent for those $16-24$, and 10 percent for those $16-17$. They found that the minimum wage had little effect on expected earnings of youth. Higher wage rates of some youths were about offset by the nonemployment of others. Had the minimum wage not been raised over this period, inflation would have greatly moderated the adverse effects of the minimum. Had the minimum remained at its 1973 level, approximately $2 / 3$ of potential employment gains from eliminating the minimum would have been attained. Their findings tend to support the hypothesis that the effects of the minimum are concentrated on youth with subminimum wage rates. They thus find no evidence that the wage rates of youth with market rates above the minimum were bid up (Meyer \& Wise, 1983). In a more recent study, David Neumark and William Wascher, on the basis of national time 
series data from the 1960 s through the 1970 s, showed that a 10 percent increase in the minimum wage apparently reduced teenage employment by 1-3 percent with proportionately smaller effects for 20-24 year olds. On the basis of panel data they concluded that youth subminimums, though not necessarily student subminimums, moderated the displacement effects of minimum wages on teenagers (Neumark \& Wascher, 1992).

The supply constrained model in recent years has offered a rejoinder to the demand constrained model, most notably through the work of Card, Katz, and Krueger. At first they challenged Neumark's and Wascher's methodology, arguing that their conclusions were contingent on whether they held constant a variable measuring the "proportion of the aged group enrolled in school." When this variable was included, the minimum wage index had a statistically significant negative effect on employment. But when this variable was excluded, the minimum wage had a "statistically insignificant and positive contemporaneous effect on teenage employment (Card, Katz \& Krueger, 1994, p. 488)." On the contrary, in a study on the effects of increasing minimum wages in California, Card showed that increases did not result in decreases in employment. During July of 1988 , California's minimum wage was raised from $\$ 3.35$-- then the prevailing federal minimum -- to $\$ 4.25$. The unemployment rate in California fell from 5.8 to 5.1 percent from 1987-1989. During the same period, the national rate fell from 6.2 to 5.3 percent. This would suggest that economic growth in California was similar to, or maybe slightly slower than, the rest of the nation. But the actual pattern was quite different for California teenagers, where the unemployment rate fell 3 percent from 16.9 to 13.9 percent. The average U.S. rate only fell by 1.9 percent from 16.9 to 15 percent. The rise in minimum wages raised the wages of low-wage workers, with no adverse effects on employment (Card, 1992). Similarly, Katz and 
Krueger found that in a study of the fast food industry, increases in the minimum wage showed little evidence of significant adverse effects of minimum wage increases on employment (Katz \& Krueger, 1992).

In another study of the fast-food industry in New Jersey and Pennsylvania, Card and Krueger found that a rise in the minimum wage, from $\$ 4.25$ to $\$ 5.05$ had little disemployment effect. The study focused primarily on New Jersey where the minimum wage raise took effect, with Pennsylvania serving as the control group. The average starting wage at fast food restaurants in New Jersey increased by 10 percent following the minimum wage increase. But the minimum wage increase had no apparent "spillover" on high-wage restaurants. Within New Jersey, employment expanded at low wage stores -- those paying $\$ 4.25$ per hour -- and contracted at high-wage stores -- those paying $\$ 5.00$ or more per hour. Employment also contracted between February and November 1992 at fast-food stores that were unaffected by the rise in minimum wage -- those stores in Pennsylvania and New Jersey paying $\$ 5.00$ or more per hour.

Card and Krueger also found little by way of a substitution effect, that there wasn't an overwhelming tendency for employers to compensate for higher wages through reductions in fringe benefits. In their initial survey, Card and Krueger found that 19 percent offered workers free meals, 72 percent offered reduced-priced meals, and 9 percent offered a combination of both free and reduced-priced meals. In their follow-up survey, they found that while the proportion of restaurants in both New Jersey and Pennsylvania offering reduced-priced meals fell after the wage hike, there was an increase in the proportion of restaurants offering free meals. And relative to Pennsylvania, New Jersey stores actually shifted towards more generous provision -- though the relative shift wasn't considered to be statistically significant. Although the minimum-wage increase 
did lead to price increases for meals, suggesting that the costs of the increase were simply passed onto the consumer, there was no evidence that prices rose faster among stores in New Jersey that were most affected by the rise in the minimum wage. Moreover, the raise in minimum wage didn't negatively affect the number of store openings, and it had no disemployment effect (Card \& Krueger, 1994).

\section{The Politics of Models}

These studies, however, have not been without their controversy. The principal concerns have been with the unknown. One such unknown is just how much can the minimum wage be raised -- even within the parameters of the Card and Krueger model -- without risking a serious disemployment effect. John Kennan, for instance, has suggested that Card and Krueger accept at face value results that show minimum wage increases will not have adverse consequences. It is simply not known that there would not be adverse consequences were the minimum wage to be increased beyond a certain threshold. Moreover, it is unlikely that we will find out even if we were to employ a more sophisticated methodology on the existing body of data. Rather what is needed is more sophisticated data (Kennan, 1995). An important subtext, often neglected, to the whole minimum wage debate is that there isn't any conclusive data to make any definitive statements about any effects at all, whether they be positive or negative. In effect the issue becomes the model and its legitimacy, with different groups having to varying degrees a stake in it. Consequently, that model which is adopted will have an impact on different groups of people. That there is this level of ambiguity in the data might suggest that the Laswell model of politics tells us more about the minimum wage than does the traditional economics text book analysis. 
Even if it isn't clear from the Card and Krueger study that increases in the minimum wage will not absolutely have a disemployment effect it should be patently clear that the evidence is at least ambiguous, which in a political context riven with interest groups renders it susceptible to manipulation. There would appear to be evidence to suggest that we may simply know very little about the minimum wage or its effects. Charles Brown has suggested that the minimum wage is essentially overrated by both critics and supporters alike. Since its passage in 1938, it has averaged a bit less than half of hourly earnings. Those who earn the minimum wage account for 612 percent of those employed and less than five percent of wage and salary income. The reduction in employment in the standard model isn't necessarily accomplished by any number of workers being discharged because the turnover rates in minimum wage jobs are on the order of $12-15$ percent per month. Nevertheless, there are complications to empirical estimates of the effects of the minimum which stem largely from the fact that the FLSA has exempted some employers. Those exempted were generally smaller oncs, with the standard of "smallness" gradually being tightened over time. As of 1988 , the uncovered sector consisted mostly of retail trade and service employees. Therefore, the basic message for empirical work is that one must account for the extent of coverage and elasticity of total unskilled employment with respect to the minimum that will be smaller than elasticity of demand. The second complication is that minimum wage workers bear no unique identifying marks besides wage rates. The effects of the minimum wage on employment are smaller than one would have supposed, and part of this small effect is due to the fallacy of inflated denomination. But it is also hard to see any evidence that minimum wage increases have benefits which would overcome an economist's aversion to interfering with reasonably competitive markets (Brown, 1988). 
The political question to arise, then, is how the focus has come to be specifically on the effects of the youth labor market? How is it that this model has become the accepted model for approaching the issue of the minimum wage? Card and Krueger have suggested that the answer may have something to do with publication bias. Through a meta-analysis of minimum wage studies, they concluded the existence of a publication bias that often results in the types of studies we are accustomed to seeing. Because journals will not publish results that aren't statistically significant and that significance is generally defined as a $t$ ratio in excess of 2 , there is a tendency for editors and reviewers to look more favorably on those studies with statistically significant results. In the case of the minimum wage this problem is compounded by the strong theoretical presumption of the economics profession that increases in the minimum wage will lead to decreases in employment. This in turn may lead to further biases in that 1) reviewers and editors may be predisposed to accepting those papers that can show a "significant negative effect" of the minimum wage; and 2) this criterion of a "significant negative effect" will become a guide to choosing empirical specifications. The choices made in this regard are then intended to ensure that the results are statistically significant (Card \& Krueger, 1995). This in part may account for the principal focus of many studies being on the youth disemployment effect.

One possible counter argument to the youth disemployment effect is that the minimum wage might be viewed as a positive vehicle for lifting those at the low end of the wage scale out of poverty. The poverty argument, as this might be referred to suggests that an increase in the minimum would make low-wage/low skill jobs attractive to those who are currently on welfare (Ellwood, 1988; Bane and Ellwood, 1994). It is the argument that individuals do respond to changes in expected net income on wealth or net prices of working and saving brought about by 
transfer programs. Although it is believed that current transfer programs do have an impact on overall labor supply, it is difficult to conclude precisely just what that impact may be (Danziger, Haveman \& Plotnick, 1981). Since much of the research on poverty shows that many on welfare don't work because it is simply too costly to do so, raising the minimum wage might have the effect of offering positive inducement to work. In addition, it would offer some measure of integrity to those jobs considered "menial" that any number of individuals who previously shunned them will now be proud to have them. Hence the principal reason for raising the minimum wage is so that those at the bottom end of the income distribution can earn a wage that places them above the poverty level.

Arguments against the poverty argument for raising the minimum wage often center on the assumption that many minimum wage earners simply aren't poor. Earners of the minimum wage are for the most part teenagers or contributing members of a household budget. Those who fall into the category of the dependent poor are not currently employed in those jobs, even though those are the jobs they would most likely qualify for (Burtless, 1995). On these grounds, it is often concluded that raising the minimum wage would not greatly help the poor. Shapiro, for instance, posed the question in terms of whether increasing the minimum wage would help the homeless. It would not, he concluded, because minimum wage workers generally aren't primary wage earners in their families. He noted that in 1986 just under 2 percent of husbands and 70 percent of wives earned the prevailing minimum wage. It was more likely that other family members -- sons and daughters -- would earn the minimum wage. In 1985, only 18.5 percent came from families with incomes below the poverty line; 11.6 percent had incomes between 100 and 150 percent of the poverty line and 69.8 percent had incomes considerably above the poverty 
line. Since most homeless don't have jobs, it is doubtful that they would be helped by an increase in the minimum wage (Shapiro, 1990-91; Burkhauser \& Finegan, 1989).

Still, there is a political problem here. Schram, for instance, has suggested that when it comes to the field of poverty research, it has become fashionable to apply social science methodologies to what is otherwise an ideological position for the purpose of giving it an imprimatur of legitimacy (Schram, 1995). As much as his is a voice from the left, there might appear to be some element of truth to it. Those who get mired in the particulars of a model often overlook the particular characteristics of those who earn the minimum wage. Those who argue against the minimum wage often argue that it wouldn't be beneficial to the poor because most of those who collect the minimum wage aren't poor. Data from the Department of Labor actually suggests that the percentage of those earning the minimum wage decreased from 1979 to 1994. Even though the percentage of those earning the minimum wage was relatively low, what is interesting is the actual decline because it also appears to coincide with a period when the minimum wage declined in value. Table I shows the declining percentage of those earning minimum wage.

Table I Percent of Hourly Paid Workers Earning Minimum Wage

$\begin{array}{cccc}\text { Year } & \text { Both Sexes } & \text { Men } & \text { Women } \\ 1979 & 13.3 & 7.7 & 20.2 \\ 1980 & 15.1 & 9.6 & 21.6 \\ 1981 & 15.1 & 9.6 & 21.2 \\ 1982 & 12.8 & 8.6 & 17.3 \\ 1983 & 12.2 & 8.4 & 16.4 \\ 1984 & 11.0 & 7.5 & 14.8 \\ 1985 & 9.9 & 6.9 & 13.2 \\ 1986 & 8.8 & 6.9 & 11.9 \\ 1987 & 7.9 & 5.4 & 10.5 \\ 1988 & 6.5 & 4.4 & 8.6\end{array}$




$\begin{array}{rrrr}1989 & 5.1 & 3.5 & 6.7 \\ 1990 & 5.1 & 3.3 & 7.0 \\ 1991 & 9.3 & 6.7 & 11.8 \\ 1992 & 7.6 & 5.7 & 9.5 \\ 1993 & 6.6 & 5.0 & 8.2 \\ 1994 & 6.2 & 4.7 & 7.8\end{array}$

Source: Drawn from Table 9, U.S. Department of Labor, Bureau of Labor Statistics, unpublished tabulations from the Current Population Survey (CPS)

It also may not be the case that most of those earning the minimum wage are teenagers.

Many are in fact over twenty five years old, though they never married. This can be seen in Table

II.

$\begin{array}{cccc}\text { Table II Percentage of Minimum Wage Earners by Sex, Marital Status and Age } \\ & \begin{array}{c}\text { Both Sexes } \\ \text { Ten }\end{array} & \text { Women } \\ \text { Total, 16 years and over } & 6.2 & 4.7 & 7.8 \\ \text { Never Married } & 11.3 & 9.4 & 13.7 \\ \text { 16 to 24 years } & 15.7 & 13.2 & 18.5 \\ \text { 25 years and over } & 5.1 & 4.3 & 6.2 \\ \text { 25 to 54 years } & 5.0 & 4.2 & 6.2 \\ \text { Married, spouse present } & 3.3 & 1.9 & 4.7 \\ \text { 16 to 24 years } & 8.5 & 5.2 & 11.4 \\ \text { 25 years and over } & 2.9 & 1.7 & 4.2 \\ \text { 25 to 54 years } & 2.7 & 1.4 & 4.1 \\ \text { Other Marital Status } & 5.4 & 2.9 & 6.9 \\ \text { 16 to 24 years } & 13.2 & 6.1 & 16.9 \\ \text { 25 years and over } & 5.1 & 2.8 & 6.5 \\ \text { 25 to 54 years } & 4.6 & 2.6 & 6.0\end{array}$

Source: Drawn from Table 7, U.S. Department of Labor, Bureau of Labor Statistics, unpublished tabulations from the CPS.

Although there is a higher percentage of women earning the minimum wage than men relatively speaking, the percentage of women earning the minimum wage in 1979 was considerably higher. The gap between men and women narrows from 12.5 in 1979 to 3.1 in 1994. Although it is true that the highest percentage of minimum wage workers are to be found among the 16-24 age cohort, there is still a considerable number of minimum wage earners outside that cohort. When 
we look at how the minimum wage has fallen in value, particularly in relation to the average annual hourly wage, we also find that during this period the minimum wage fell from a value of close to 50 percent to less than 40 percent. This can be seen in Table III.

\begin{tabular}{|c|c|c|c|}
\hline Year & Minimum & Annual Average & Percentage \\
\hline 1938* & $\$ .25$ & $\mathrm{NA}$ & NA \\
\hline $1939 *$ & .30 & NA & NA \\
\hline 1945 & .40 & NA & NA \\
\hline 1947 & .40 & $\$ 1.13$ & 35.4 \\
\hline $1950 *$ & .75 & 1.33 & 56.4 \\
\hline $1956^{*}$ & 1.00 & 1.80 & 55.6 \\
\hline $1961 *$ & 1.15 & 2.14 & 53.7 \\
\hline $1963 *$ & 1.25 & 2.28 & 54.8 \\
\hline $1967 *$ & 1.40 & 2.68 & 52.2 \\
\hline $1968 *$ & 1.60 & 2.85 & 56.1 \\
\hline $1974 *$ & 2.00 & 4.24 & 47.2 \\
\hline $1975^{*}$ & 2.10 & 4.53 & 46.4 \\
\hline $1976 *$ & 2.30 & 4.86 & 47.3 \\
\hline $1978 *$ & 2.65 & 5.69 & 46.6 \\
\hline $1979 *$ & 2.90 & 6.16 & 47.1 \\
\hline $1980^{*}$ & 3.10 & 6.66 & 46.5 \\
\hline $1981 *$ & 3.35 & 7.25 & 46.2 \\
\hline $1990 *$ & 3.80 & 10.01 & 38.0 \\
\hline $1991 *$ & 4.25 & 10.32 & 41.2 \\
\hline 1995 & 4.25 & 11.46 & 37.1 \\
\hline
\end{tabular}

* These are the years that increases in the minimum wage took effect.

Source: "History of the Federal Minimum Wage Rates Under the Fair Labor Standards Act -- 1938 Through 1991," U.S. Department of Labor, Employment Standards Administration; Bureau of Labor Statistics, Labstat Series Report, Current Employment Statistics, Series EEU00500006

If there is a relationship, it would seem to have some critical implications. On the one hand, it might be inferred that fewer people earning the minimum wage is a measure of progress in that fewer minimum wage earners might presuppose that these workers have been successful in moving out of minimum wage jobs. This is clearly an argument that supporters of the "Demand 
constrained" model are likely to make. On the other hand, it is perhaps disturbing that this trend does coincide with the declining value of the minimum wage. We are perhaps left to wonder whether those who were earning the minimum wage previously didn't simply drop out because the value of the wage was simply inadequate. Many of these people, especially women with children, could receive greater income through public assistance programs. If this is true, it would lend support to the notion that a higher wage, or at least one that more closely approximates 50 percent of annual average hourly earnings, will attract those at the low end of wage scale into the labor market. It is the latter argument that we are more likely to see from those supporters of the "Supply constrained" model.

But it might also explain why the youth labor market has become the principal focus of the debate. If the result of declining value is that the only labor market willing to accept such wages are youth, it becomes a foregone conclusion that they will become the primary subject of the debate. That this group might bear some costs as a function of increasing the minimum wage still does not prove that there is data on the former and none on the latter. It might well be that the focus on the youth labor market speaks more to the politics of the issue and less to the substantive issues inherent to either model. In the absence of hard core empirical data, all there is is theory and theoretical presuppositions. In any policy issue, politics is bound to rear its head, but all the more so when there is no conclusive data one way or the other.

But as Levitan and Belous suggest, the particular focus on the teen labor market has nonetheless had a distortive effect, for it could be misleading, if not altogether incorrect, to extend these findings to the adult labor market. " That the minimum wage creates some unemployment does not help policymakers in drafting a wage floor program. More important is how much 
unemployment is created by the wage floor (Levitan \& Belous, 1979, p. 150)." On the contrary, they suggest that the dire predictions offered by neo-classical economists speak more to their ideological biases and have little support in empirical research. As they see it, the best evidence suggests that the minimum wage has not been a major cause of unemployment. Although some job loss has been detected, it has been considerably smaller than that alleged by orthodox economists. Statistical evidence actually suggests that a wage floor has the power to increase significantly the wages of the working poor. And while minimum wages may result in some unemployment and other negative effects for adult workers, the income gains due to that minimum are far greater than any injury. Adult workers on balance appear to be made better off under a wage floor, although the tradeoff for teenagers may be even more pronounced (Levitan \& Belous, 1979, pp. 151-153). To some extent this argument is similar to one made by Freeman and Medoff with regards to unions. Although there may be some reduced profitability for many unionized firms, there may still be some social efficiency gains arising from wage and other securities derived from collective bargaining agreements (Freeman \& Medoff, 1984).

The reality, however, is that there may be no conclusive data because the minimum wage has been so low, relative to other wages, that it couldn't possibly make a difference. That is, minimum wage increases have been so inconsequential that it is hard to detect the impact. According to a study by Alida Castielo Freeman and Richard Freeman (1991), while the minimum is a classic textbook example of government setting the price of labor, it is also one of the few clear tests of economics of derived demand. The estimated reduction of employment for teenagers is often imprecisely determined or "smaller" than one would expect. There are essentially three explanations consistent with labor demand analysis for why research yields weak results on 
employment effects of the U.S. minimum. One is that there is considerable noncompliance with the minimum wage, thereby making the law ineffective. Second, employers may respond to the minimum by reducing fringe benefits, training, and quality of work conditions to a greater extent than employment. And third, the minimum may have been so low, especially in the 1980 s, that it disemployed too few workers to be detectable in a world where shifts in supply and demand schedules create considerable random variation in employment. Rather, in order to find a clear employment effect, one must examine a minimum wage that bites rather than nibbles at the edges of the job market. To test this out, the Freemans examined the extension of the U.S. federal minimum to Puerto Rico during the 1970 s. There the average hourly pay on the island was roughly half of that on the mainland, in which case the effects of the minimum would have been roughly the equivalent of doubling the minimum in the U.S. What the case of Puerto Rico showed was that the extension of the minimum wage did have the clear-cut effects typical of a textbook diagram (Freeman \& Freeman, 1991, pp.1-2 ). But it also had to be clear that the increase would indeed be significant. Robert Gordon too, has alluded to this by suggesting that minimum wage increases may simply not have had the predicted text-book effect because it was so much lower than a market clearing wage (Gordon, 1995).

We don't know that a sizeable segment of the population would not be helped by an increase in the minimum wage; only that the prevailing model suggests that an increase in the minimum wage would result in a youth disemployment effect. There really isn't any data to prove that an increased minimum wage would not assist these people. It doesn't necessarily follow that because many of these individuals don't currently hold minimum wage jobs they wouldn't be

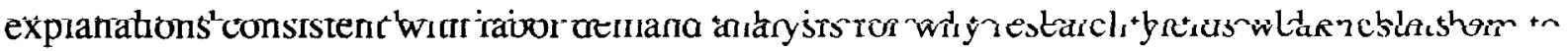


work. On the contrary, the general ambiguity in the data would appear to lead to the conclusion that there isn't sufficient data to make such a determination. Rather determinations are based on generalizations on the basis of what minimum wage positions have attracted. On the contrary, if it can be shown that slight increases in the minimum wage will not affect those who might receive greater benefit from the welfare system, the poverty argument is effectively disqualified. All we are left with, then, is the ill effect on the teen labor market? Since teenagers have little political clout, the effect is to have greater support for keeping the minimum where it is -- and even to have sub-minimums -- than to raise them. And yet, it still has not been proven that the poor will not be helped; only that we simply do not have data.

\section{Failure of Poverty Arguments?}

Another way to pose the question is to ask just why haven't poverty arguments been strong enough to induce increases in the minimum wage? Or why is it that the only apparently viable defense against poverty arguments are the supposed ill effects on the teen labor market? Why hasn't the other side of the story been heard? Although economic arguments will certainly be given their due, it is hard to believe that members of Congress will give greater consideration to the merits of a model than their constituent interests.

On one level, the minimum wage is a question of whether a wage floor will have an adverse effect on employment or a beneficial effect on specifically targeted groups. But on another level, it is a question of how it impacts regions of the country differently. It should first be noted that an increase in the minimum wage would not have the same effect on all regions of the country. In those regions of the country where wages are relatively high, an increase in the 
minimum is likely to have less of an impact on the overall wage structure than in those regions where wages are relatively low. Moreover, in those regions where the legal climate is favorable to business through "right-to-work" laws, because unionization is weak -- effectively resulting in the absence of a wage floor -- a legal wage floor could have much more of an impact. More to the point, in those regions where "right-to-work" laws exist, the lobby for an increase in the minimum wage will be less. That lobby has traditionally been organized labor.

One argument for why the poverty argument has been ineffectual is because in contemporary political discourse poverty programs are generally under assault (Schram, 1995; Katz, 1989). So if the minimum wage is couched as a poverty argument, it is bound to fail whereas if couched as a larger labor issue with the full political support of labor constituents it is more likely to succeed. The chief labor constituents would be organized labor, but labor unions have generally been in a state of decline since the $1950 \mathrm{~s}$, and ever more so since the early $1980 \mathrm{~s}$.

The period of greatest stagnation for the minimum wage also appears to have been a period when organized labor suffered its greatest decline. 1981, in particular, was a watershed for labor, as it was when then President Ronald Reagan fired the PATCO air traffic controllers. Piore reminds us that Reagan's action against PATCO “galvanized anti-union managerial factions in a whole variety of industries and occupations where union organization had previously been unassailable. And it set the stage for a prolonged period of union give backs and concession bargaining." 1981 was also the last time that the FLSA would be amended until 1989. The minimum wage was essentially allowed to fall relative to average wages, from 47 percent to 35 percent. And this was the longest and most sustained decline since its introduction in the 1930s (Piore, 1995, pp. $10 \& 14$ ). But as Keeran and Tarpinian also suggest, more important than 
Reagan's decertification of PATCO and the firing of its striking members was his anti-union appointments to the NLRB. As a result those companies operating during a strike in the $1980 \mathrm{~s}$ found a strong ally in the law (Keeran \& Tarpinian, 1989-90). And to suggest that 1981 was a watershed by no means dismisses the trends in many southern states towards "right-to-work" laws which effectively barred closed shops. Such laws provide that no one shall be required to belong to a union or not to as a condition of employment, and that no collective bargaining agreement shall impose such a requirement (Rees, 1989, p. 113). One school of thought even suggests that management during the 1970s and 1980s embarked on a systematic plan to undercut labor by closing plants and relocating facilities to more favorable business climates. By closing down one plant and punishing its workers, workers in other plants would be forced into more serviceable behavior (Bowles, Gordon \& Weisskopf, 1983).

Unions would appear to have something in common with minimum wage legislation, not merely because they seek to accomplish the same goals -- ultimately the establishment of a minimum level of subsistence -- but because congressional support would appear to be stronger in those areas where union density is higher. Politically speaking, it would be easier to support a legal wage floor in those regions where unions have successfully created a prevailing wage rate. The unions, in other words, have already done the heavy lifting and the statutory wage floor becomes an added layer of protection. But in those regions where no prevailing wage rates exist because there have been no unions to do the heavy lifting, the statutory wage floor is more likely to have an impact on the overall wage structure. To put it differently, those states that have already signaled the desire to maintain low wage rates through laws generally perceived to be hostile to unions, are not going to be any more amenable to legislation that does for the entire 
labor market what unions have only been able to accomplish for a very small segment.

The union also has an interest in supporting increases in the minimum wage insofar as an increase may effectively increase the demand for skilled labor. As skilled workers tend to be unionized, unions are only increasing the demand for their own labor by supporting higher minimum wages (Kau \& Kau, 1973; Hobson \& Maurice, 1983). But unions also have an interest in supporting higher minimum wages insofar as they create a stronger cushion for themselves. A viable wage floor, especially during hard economic times, would create an absolute limit to the concessions labor might be forced to give. Or stated differently, a high minimum wage could effectively result in "right-to-work" laws having less of a negative effect on wages in certain regions of the country.

\section{Congressional Voting}

Evidence of the declining influence of unions along with different regional interests would appear to be evident in congressional voting patterns. From a theoretical stance, in attempting to understand the voting behavior of members of Congress, we would expect that representatives from those states with higher union density to vote for minimum wage increases while those with lower densities -- particularly those from "right-to-work" states to vote against. Although union density overall is very low, there are clearly relative differences between states. On the whole, union density, as might be expected, is lower in those states that have "right-to-work" laws. Because there is no label which easily captures the exact opposite of "right-to-work," the only basis upon which we can measure the opposite is higher union density. A look at the percentage of unionized labor on a state by state basis shows Northern industrialized states to have higher 
concentrations of unionized workers than Southern states, and particularly those with right to work laws. This can be seen in Table IV.

Table IV Percentage of Unionized Workers

\begin{tabular}{|c|c|c|}
\hline State & Percentage & Rank \\
\hline Alabama* & 13.6 & 25 \\
\hline Alaska & 23.1 & 4 \\
\hline Arizona* & 8.0 & 41 \\
\hline Arkansas* & 7.8 & 42 \\
\hline California & 17.7 & 15 \\
\hline Colorado & 9.9 & 33 \\
\hline Connecticut & 20.2 & 9 \\
\hline Delaware & 13.0 & 26 \\
\hline D.C. & 15.1 & 22 \\
\hline Florida* & 7.3 & 44 \\
\hline Georgia* & 6.8 & 46 \\
\hline Hawaii & 24.6 & 2 \\
\hline Idaho* & 8.1 & 40 \\
\hline Illinois & 20.2 & 8 \\
\hline Indiana & 16.5 & 17 \\
\hline Iowa* & 12.1 & 29 \\
\hline Kansas* & 10.2 & 31 \\
\hline Kentucky & 12.6 & 27 \\
\hline Louisiana* & 7.0 & 45 \\
\hline Maine & 15.6 & 21 \\
\hline Maryland & 14.9 & 23 \\
\hline Massachusetts & 16.2 & 19 \\
\hline Michigan & 23.7 & 3 \\
\hline Minnesota & 20.3 & 7 \\
\hline Mississippi* & 5.2 & 49 \\
\hline Missouri & 14.6 & 24 \\
\hline Montana & 15.8 & 20 \\
\hline Nebraska* & 9.1 & 38 \\
\hline Nevada* & 20.2 & 10 \\
\hline New Hampshire & 12.6 & 28 \\
\hline New Jersey & 21.9 & 5 \\
\hline New Mexico & 9.4 & 35 \\
\hline New York & 27.7 & 1 \\
\hline North Carolina* & 4.2 & 50 \\
\hline North Dakota* & 10.0 & 32 \\
\hline Ohio & 18.5 & 14 \\
\hline
\end{tabular}




$\begin{array}{lrr}\text { Oklahoma } & 9.3 & 36 \\ \text { Oregon } & 20.1 & 11 \\ \text { Pennsylvania } & 18.9 & 13 \\ \text { Rhode Island } & 19.4 & 12 \\ \text { South Carolina* } & 3.3 & 51 \\ \text { South Dakota* } & 7.7 & 43 \\ \text { Tennessee* } & 9.5 & 34 \\ \text { Texas* } & 6.5 & 48 \\ \text { Utah* } & 9.0 & 39 \\ \text { Vermont } & 9.3 & 37 \\ \text { Virginia* } & 6.7 & 47 \\ \text { Washington } & 21.0 & 6 \\ \text { West Virginia } & 16.3 & 18 \\ \text { Wisconsin } & 17.7 & 16 \\ \text { Wyoming* } & 11.2 & 30\end{array}$

* State has right-to-work-law Source: Drawn from Table 8 in Barry T. Hirsch and David A. Macpherson, Union Membership and Earnings Data Book: Compilations from the Current Population Survey (1996 Edition) (Washington, The Bureau of National Affairs, Inc., 1996), pp. 22-23

The key question is how members have traditionally voted on the issue. As a general rule, Democrats tend to vote for increases while Republicans vote against. Because these tendencies conform to preconceived notions, there is nothing interesting in this per se. What is interesting are the exceptions to these general rules. In the remainder of the paper I look at the congressional voting patterns of three major episodes in minimum wage legislation: 1955, 1977 and 1989.

The increase of 1955 is important because, in addition to being the first increase since the 1940s, it also represented a significant anomaly. In 1955, a Republican president specifically introduced legislation to raise the minimum wage, and most of the party closed ranks. But it was also a critical period because it was a clear example of union activism on the issue. In January of 1955, during his State of the Union address, President Eisenhower urged modification of the FLSA by calling for an increase to ninety cents an hour. Trade unions viewed this message as a 
green light to resume their campaign for a higher and more broadly based minimum wage.

Overall, the political environment appeared to be somewhat conducive. For one thing, the last revision had not been since 1949 and the 75 cents an hour minimum wage was no longer viewed as adequate. Moreover, the 1954 elections brought the Democrats back to power and in control of both chambers of Congress. And with them came a slightly larger contingent of candidates with labor endorsements. Also both the AFL, and CIO in their separate conventions had passed resolutions urging an increase in the minimum from $\$ .75$ to $\$ 1.25$ and an extension of the coverage.

Four unions in particular had a stake in the increase: The International Ladies' Garment Workers Union; the Amalgamated Clothing Workers of America; the Textile Workers Union of America; and the Cap and Millinery Workers. The industries covered by the four unions were producers of light products that were typically transported for sale in nationally competitive markets. As they saw it, those low-wage producers operating at the federal minimum constituted a threat to the organized sector, with the capacity to produce unemployment, wage cuts, or wage freezes in the unionized sector. A higher minimum wage would close, or at least narrow, the competitive gap, thereby serving to preserve employment in unionized plants. Thus the four unions came together to create an ad hoc committee that was to be formalized as the Joint Minimum Wage Committee with headquarters in Washington. Its principal responsibility was to spearhead the legislative effort to raise the wage. The Committee was to be headed by Arthur Goldberg, a prominent labor attorney who would go on to be the U.S. Secretary of Labor in the Kennedy administration before being appointed to the Supreme Court.

The Committee adopted a strategy which consisted of four basic steps: 1) The committee 
would urge as many members of Congress as it could to submit their own minimum wage bills. It sought to do this by visiting individual members of Congress; 2) The Committee planned a visit with the President by the presidents of the international unions. The goal here was to raise the level of publicity to that of a foreign summit; 3) The Committee planned interviews between top union leaders and the House and Senate leadership. These conferences were intended to make it clear that the unions really meant business, and that they weren't simply carrying on routine agitation for another measure; and 4) The regular legislative offices of both the AFL and CIO gave the same message to Congressmen in general.

By mid-March, the Committee had settled on a focus, which was to work up public interest in a minimum of $\$ 1.25$ as that which was ultimately desirable and justifiable, but settle on something between $\$ .90$ and 1.25 . It also planned to build up testimony for extended coverage with the understanding that action on coverage might have to be postponed. The difficulty, however, was going to come from Graham A. Barden (D-N.C.) who was chair of the House Committee on Education and Labor. And for a while it appeared as though it would be a struggle between organized labor and Barden. Barden ruled the committee with a firm hand and he had the votes to back him up. Consequently, the Committee sought to circumvent the House Labor Committee by starting action in the Senate, where it had an ally in Senator Paul Douglas of Illinois. The Committee also sought to drum up grass roots support for an increase. The principal effort was to get "communities" to communicate with Congressmen, rather than trade unionists alone. The assumption was that a higher minimum wage would be of interest to the "community" and that it was the union's job to motivate the community to voice that interest. To do this the Committee prepared regional staff to go out and talk with members of the community. It prepared 
handbooks explaining why the minimum wage was first implemented and why it needed to be increased. Although the end result was a compromise of a $\$ 1.00$ minimum wage, it is important to note that at no point were any arguments about relieving poverty advanced. The minimum wage simply was not viewed in those terms. It in part came about because the President set the tone for a non-partisan effort by introducing it. But it also came about in larger measure because of the strong efforts of organized labor.

The 1977 episode is important because it was the last vote on the minimum wage until 1989. It also set into motion a phased-in wage increase with the last increase taking effect in 1981, which itself was the last increase until 1989. Whereas the 1955 round is indicative of union strength, 1977 is somewhat revealing in its relative weakness. Still, there are lessons to be drawn about the importance of labor. During the 1977 round, pro-minimum-wage forces attempted to end the historical pattern of minimum-wage setting by first increasing the wage floor to a higher relative rate than in most previous rounds, and second by indexing the wage floor to inflation so that future adjustments would be automatic. Organized labor, as represented by the AFL-CIO, proposed an immediate thirty percent increase from the existing rate of $\$ 2.25$ to $\$ 3.00$. They also called for an automatic mechanism to be grounded into law that would keep the minimum wage at 60 percent of the average hourly manufacturing sector wage. As labor saw it, these demands were in essence the "bread and butter issues of wages and jobs (Levitan \& Belous, 1979,p 130)."

Though there was some support among Democratic members of Congress, the Carter administration wasn't willing to support a wage as high as that proposed by the AFL-CIO. Moreover, the Carter administration didn't feel as beholden to labor as had past administrations because the labor vote during the 1976 presidential primaries had actually gone to Carter's 
opponents, many of whom had stronger ties to labor. Feeling free from this political constraint, the Carter administration felt that it could back some sort of compromise that might provide some assistance to the working poor without creating too much of an inflationary pressure. The Carter administration's more modest proposal had called for an immediate increase to $\$ 2.50$ an hour with future minimum levels to be adjusted annually so that they would always remain equal to 50 percent of average manufacturing wages (Eccles, 1977, p. 640). As it turned out, a majority of the House Education and Labor Committee favored the addition of indexing as an integral part of a wage floor on the premise that the working poor should not have to await the findings of a commission as their already meager incomes were being eroded. The committee also reasoned that employers too would benefit from stable and regular patterns of change, as this would allow both workers and business executives to anticipate and plan for the increases. While opponents of indexation argued that it was inflationary in addition to an impediment to Congressional oversight, the majority of the committee viewed the periodic review process to be unproductive and a waste of Congress's time and effort. Moreover, it was simply unfair for those working poor dependent on minimum wages to see their wages held captive to the whims of the political process which inevitably had to satisfy the diversity of interest groups (Levitan \& Belous, 1979, pp. 122-132). In the end, a compromise was reached whereby the minimum wage would be increased in stages over a three year period. Although the end of this staged process would see a minimum wage in excess of $\$ 3.00$, it wasn't the immediate increase requested by labor. And ultimately, the idea of indexation fell by the wayside. The compromise reached was to raise the minimum wage through four phase-ins in lieu of indexation. When the issue of a minimum wage increase would come up again in 1987, Lane Kirkland, then president of the AFL-CIO noted in Congressional testimony 
that the AFL-CIO had indeed been disappointed when in 1977 Congress had considered but failed to index the minimum wage. Had that indexation occurred, the minimum wage would have reached $\$ 4.45$ by 1987 (Kirkland, 1987, p. 297). Still, we are left to wonder whether the AFLCIO plan might not have been fully enacted had labor had a better relationship with the administration. At the same time, however, it becomes clear that the process of raising the minimum wage, regardless of the final outcome, did involve -- and most likely required -- the active participation of labor as a major player.

Lastly, 1989 is important because it was the last vote until the present, although it set into motion a two-staged implementation process. Beginning in 1955 we can begin to see some very interesting things, Although most members of Congress overwhelmingly voted in favor of the wage increase, including most Republican members, a sizeable number of Democratic members of the House also voted against the minimum wage and again they were primarily from the "right-towork" states. In fact, there were more Democratic members of Congress voting against the increase than Republican members. In Table V we can see from which states both Democratic votes against and Republican votes for come from.

\section{Table $V$ Votes on the Minimum Wage}

Democratic Votes Against

1955

Alabama*

Arkansas*

Georgia*

Mississippi*

South Carolina* $(\mathrm{H})$

Tennessee*

Texas*
(H)

(H)

(H)

(H)
1977

Alabama*
Arizona*
Arkansas*
Florida*
Georgia*
Iowa*
Kentucky

Alabama*

$(\mathrm{H} \& \mathrm{~S})$

(H)

(H)

(H \& S)

(H)

(H)

(H)
1989

Colorado

Florida*

Georgia*

Louisiana*

Maryland

Minnesota

Mississippi*
(H)

(H)

(H) 


\begin{tabular}{|c|c|c|}
\hline Virginia* $\quad(\mathrm{H})$ & 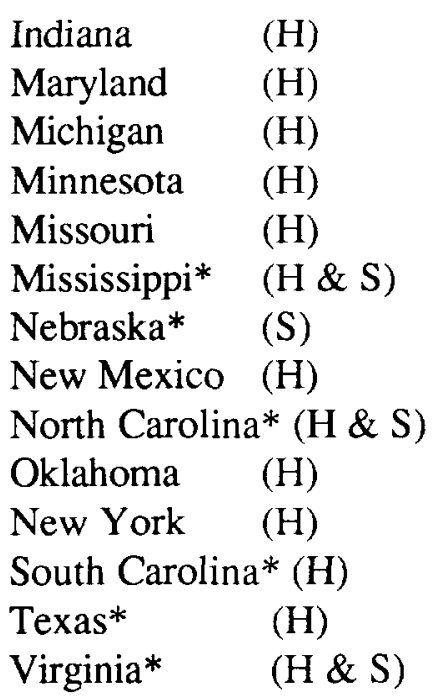 & $\begin{array}{ll}\text { North Carolina } & (\mathrm{H}) \\
\text { Oklahoma } & (\mathrm{H} \& \mathrm{~S}) \\
\text { South Carolina } & (\mathrm{H} \& \mathrm{~S}) \\
\text { Texas* } & (\mathrm{H}) \\
\text { Virginia* } & (\mathrm{H})\end{array}$ \\
\hline
\end{tabular}

Republican Votes for

\begin{tabular}{|c|c|c|}
\hline Alabama & $(\mathrm{H})$ & Alaska \\
\hline Alaska & (S) & California \\
\hline Connecticut & $(\mathrm{S})$ & Connecticut \\
\hline Illinois & $(\mathrm{H})$ & Iowa \\
\hline Maine & (H) & Illinois \\
\hline \multirow{2}{*}{\multicolumn{2}{|c|}{ Massachusetts (S) }} & Maine \\
\hline & & Massachusetts $(\mathrm{H})$ \\
\hline Minnesota & (H) & Maryland \\
\hline \multirow[t]{3}{*}{ New Jersey } & $(\mathrm{H} \& \mathrm{~S})$ & Michigan \\
\hline & & Minnesota \\
\hline & & North Dakota (S) \\
\hline New Mexico & (S) & New Jersey \\
\hline \multirow[t]{2}{*}{ New York } & $(\mathrm{H} \& \mathrm{~S})$ & New York \\
\hline & & Oregon \\
\hline Oregon & $(\mathrm{S})$ & Pennsylvania $(\mathrm{H} \& \mathrm{~S})$ \\
\hline \multirow[t]{2}{*}{ Pennsylvania } & $(H \& S)$ & Rhode Island $(\mathrm{H} \& \mathrm{~S})$ \\
\hline & & South Dakota (S) \\
\hline Tennessee & $(\mathrm{H} \& \mathrm{~S})$ & Vermont \\
\hline Washington & $(\mathrm{H})$ & \\
\hline Vermont & (S) & \\
\hline
\end{tabular}

* States with "Right-to-work" laws

$\mathrm{S}=$ votes from the Senate; $\mathrm{H}=$ votes from the House of Representatives

Source: Drawn from Congressional Quarterly Weekly Report (July 22, 1955), pp.894-895; 
(October 15, 1977), pp. 2210-2211; and (October 22, 1977), p. 2278-2279

In 1955, Republicans overwhelmingly voted for the increase. The story there was actually among those who voted against. Out of 221 Democrats in the House who voted, 29 voted against. In 1977 there were 282 Democratic members of the House of whom 63 voted against he minimum wage. In the Senate, there were 54 Democrats of whom seven voted against. On the Republican side, of the 141 members in the House 17 voted for the increase whereas in the Senate seven out of 33 voted for the increase. In 1989, 24 out of 224 Democrats in the House voted against the increase whereas in the senate only two out of 52 voted against. On the Republican side, 22 out of 147 in the House voted for the increase whereas 10 out of 35 voted for it in the Senate. Proportionate to their numbers, more Democrats in the House of Representatives appear to vote against increases than do Republicans voting for it. But in the Senate, more Republicans appear to vote for it than Democrats voting against. Generally speaking, most Democratic votes in all three episodes tend to come from "right-to-work" states whereas most Republican votes for, with some exceptions, come from those states with union densities above 10 percent.

\section{Implications}

That Democratic members of Congress are willing to vote against the position of their party at a minimum demonstrates the inability of modern day political parties to enforce discipline on its members. This, of course, is nothing new. What is more important, however, is the apparent view different regions of the country take to the issue. On one level the fact that members from those regions with high union densities -- particularly Republican members -- are willing to vote for the increase, it might imply that a key interest group in affecting how members 
vote is organized labor. On another level, the fact that most Democratic votes against the minimum wage comes from those regions where there are "right-to-work" laws, it might be concluded that the minimum wage, at least in certain areas, has a detrimental effect on the wage structure, and this runs contrary to many interests in the area. That is, if certain regions passed "right-to-work" laws with the intention of becoming more competitive and hoping to attract greater capital investment, the minimum wage is viewed as an issue affecting their ability to compete competitively. It might also be inferred, then, that those representatives in the industrial sections who support minimum wage increases view it as a measure which, in part, will stem the flow of capital investment -- ultimately jobs -- from their regions to the lower wage areas, most notably "right-to-work" states. If representatives vote in the interests of their constituents, they are clearly doing so in these regions of the country. Moreover, they are voting on the face of those interests wielding greater power. But it also isn't difficult to see how the minimum wage has become an issue wrapped up in the more traditional competition between states for capital investment (Eisinger, 1988).

It is actually understandable why Democrats from "right-to-work" states might vote against the minimum wage. What is more peculiar is that there are a handful of Republicans willing to vote for it. And while union density is those states may be higher relative to "right-towork" states, it is still considerably low relative to the overall workforce. Why, then, are they willing to vote for the wage? One reason might be the obvious moral concern of fairness -- that they believe that raising the wage of those at the bottom end of the scale is the right thing to do. But when we stop to consider that increases often tend to be limited, one then has to wonder why more don't see themselves able to do the right thing. The fact that increases have been so minimal 
may lead to yet another plausible explanation. That increases are so much below equilibrium wages means that representatives who support increases can effectively lend their moral support to an issue without having to worry that it will have a serious negative effect on people. Of course, if it is true that there is little negative effect, why is there so much opposition to the concept? The only explanation that can be offered is the traditional one of the slippery slope, that once government intervenes in one area there is no telling how far it may go.

Nevertheless, the trends in voting only reinforce the notion that the minimum wage is a political issue. From a policy stand point, it would imply that because conclusive data on the effects of minimum wage does not exist, whether the wage is raised or remains where it is likely to be a question of which interest is best able to persuade policymakers. In the realm of politics, then, reasons for raising the minimum wage stand on an equal footing with those for not raising the minimum wage. One thing, however, would appear to be clear: By focusing the issue on the teenage labor market and denying any positive potential bencfits to poor people -- as though it is an either/or proposition -- the issue of the minimum wage has effectively been removed from the labor market -- which may be viewed as a positive area of policy debate -- and lodged with those elements who have attached to them social stigma. By transforming the minimum wage into a poverty issue, the political imperative for action has effectively been diminished. The question, however, is whether in the absence of union power to maintain the minimum wage as specifically a labor issue, it wasn't inevitable that it would become a poverty issue where it has effectively been marginalized.

The debate, then, needs to be refocused, back from poverty to a traditional labor market issue -- perhaps even a labor-management issue. I am not suggesting that the answer necessarily 
lies in strengthening labor unions, though that in and of itself wouldn't necessarily be a bad thing. But the answer does lie in returning the minimum wage to the broader spectrum of issues that usually fall under the rubric of labor market concerns. This would further serve to demonstrate why the minimum wage affects us all; not just a particular segment of the population -- one that lacks serious political clout. Moreover, it would force managers to explain just why a high-wage strategy -- though clearly in the interests of most -- wouldn't be in their interests. Politically, it would become even harder for managers to make their case for a low-wage economy.

\section{References}

Alterson, James B. 1989-90. “The Prospects for Labor Law Reform," Political Studies Journal. 18,2 (Winter):364-373.

Bane, Mary Jo and David T. Ellwood. 1994. Welfare Realities: From Rhetoric to Reform. Cambridge, MA: Harvard University Press.

Bowles, Samuel, David M. Gordon and Thomas E. Weisskopf. 1983. Beyond the Wasteland: $A$ Democratic Alternative to Economic Decline. New York: Doubleday.

Brown, Charles. 1988. "Minimum Wage Laws: Are They Overrated?" Journal of Economic Perspectives. 2,3 (Summer):133-145.

Burkhauser, Richard V. and T. Aldrich Finegan. 1989. "The Minimum Wage and the Poor: The End of a Relationship." Journal of Policy Analysis and Management. 8,1:53-71.

Burtless, Gary. 1995. "Employment Prospects of Welfare Recipients." in Demetra Smith Nightingale and Robert H. Haveman, ed., The Work Alternative: Welfare Reform and the Realities of the Job Market. Washington: The Urban Institute Press.

Card, David. 1992. "Do Minimum Wages Reduce Employment? A Case Study of California, 1987-1989." Industrial and Labor Relations Review. 46,1 (October):38-51.

and Alan B. Krueger. 1995. "Time-Series Minimum-Wage Studies: A Metaanalysis." AEA Papers and Proceedings. 85,2 (May): 
1994. "Minimum Wages and Employment: A Case Study of the Fast-Food Industry in New Jersey and Pennsylvania." The American Economic Review. 84, 4 (September): 772-793.

Card, David. Lawrence F. Katz and Alan B. Krueger. 1994. "Comments on David Neumark and William Wascher, 'Employment Effects of Minimum and Subminimum Wages: Panel Data on State Minimum Wage Laws." Industrial and Labor Relations Review. 47,3 (April):

Danziger, Sheldon, Robert Haveman and Robert Plotnick. 1981. "How Income Transfer Programs Affect Work, Savings, and the Income Distribution: A Critical Review." Journal of Economic Literature. 19 (September):975-1028.

Delaney, John Thomas. 1991. "The Future of Unions as Political Organizations." Journal of Labor Research. 12,4 (Fall):373-387.

Dunlop, John T. 1966. Wage Determination Under Trade Unions. New York: Augustus M. Kelley Publishers.

Eccles, Mary Eisner. 1977. "Labor 'Disappointed' in Carter's Performance." Congressional Quarterly Weekly. (April 9)

Eisinger, Peter K. 1988. The Rise of the Entrepreneurial State: State and Local Economic Development Policy in the United States. Madison: The University of Wisconsin Press.

Ellwood, David T. 1988. Poor Support: Poverty in the American Family. New York: Basic Books.

Freeman, Alida Castello. and Richard B. Freeman. 1991. "Minimum Wages in Puerto Rico: Textbook Case of a Wage Floor?" NBER Working Paper No. 3479 (June).

Freeman, Richard B. and James L. Medoff. 1984. What Do Unions Do? New York: Basic Books.

Goldfield, Michael. 1987. The Decline of Organized Labor in the United States. Chicago: University of Chicago Press.

Gordon, Robert J. 1995. “Is There a Tradeoff Between Unemployment and Productivity Growth?” NBER Working Paper. 5081 (April).

Hobson, Margaret Jane and S. Charles Maurice. 1983. Minimum Wage Laws: Who Benefits, Who Loses. Series on Public Issues No. 2. College Station: Center for Education and Research in Free Enterprise, Texas A\&M University.

Katz, Lawrence F. and Alan B. Krueger. 1992. "The Effect of the Minimum Wage on the Fast- 
Food Industry." Industrial and Labor Relations Review. 46,1 (October): 6-21.

Katz, Michael B. 1989. The Undeserving Poor: From the War on Poverty to the War on Welfare. New York: Pantheon Books.

Kau, James B. and Mary L. Kau. 1973. "Social Policy Implication of the Minimum Wage Law." Policy Sciences. 4:21-27.

Donald Keenan and Paul H. Rubin. 1982. "A General Equilibrium Model of Congressional Voting." The Quarterly Journal of Economics. 97,2 (May):271-293.

Keeran, Roger and Greg Tarpinian. 1989-90. "Public Policy and the Recent Decline of Strikes." Policy Studies Journal. 18,1 (Winter):464-466.

Kennan, John. 1995. “The Elusive Effects of Minimum Wage.” Journal of Economic Literature. 33 (December):1950-1965.

Kingdon, John W. 1984. Agendas, Alternatives, and Public Policies. Boston: Little, Brown and Co.

Laswell, Harold. 1936. Politics---Who Gets What, When How. New York: McGraw Hill.

Levitan, Sar A. and Richard S. Belous. 1979. More Than Subsistence: Minimum Wages for the Working Poor. Baltimore: The Johns Hopkins University Press.

Mayhew, David R. 1974. Congress: The Electoral Connection. New Haven: Yale University Press.

Meyer, Robert H. and David A. Wise. 1983. "The Effect of the Minimum Wage on the Employment and Earnings of Youth." Journal of Labor Economics. 1,1:66-100.

Neumark, David. and William Wascher. 1992. "Employment Effects of Minimum and Subminimum Wages: Panel Data on State Minimum Wage Laws." Industrial and Labor Relations Review. 46,1 (October):55-81.

Piore, Michael J. 1995. Beyond Individualism. Cambridge, MA: Harvard University Press. and Charles F. Sabel. 1984. The Second Industrial Divide: Possibilities for Prosperity. New York: Basic Books.

Prasch, Robert E. 1996. "In Defense of the Minimum Wage." Journal of Economic Issues. 30,2 (June):391-397. 
Rees, Albert. 1989. The Economics of Trade Unions. Chicago: University of Chicago Press.

Schram, Sanford F. 1995. Words of Welfare: The Poverty of Social Science and the Social Science of Poverty. Minneapolis: University of Minnesota Press.

Shapiro, Daryl Marc. 1990-91. "Will an Increased Minimum Wage Help the Homeless?" University of Miami Law Review. 45:651-699.

Stone, Deborah A. 1988. Policy Paradox and Political Reason. New York: HarperCollins Publishers.

U.S. Senate. 1987. Hearings before the Committee on Labor and Human Resources. Minimum Wage Restoration Act of 1987. 100th Congress, 1st session, S.837, June 17 \& 23, 1987. Washington: Government Printing Office. 